\title{
PENGARUH PERIODE PENYINARAN TERHADAP PERTUMBUHAN DAN SINTASAN LARVA UDANG GALAH (Macrobrachium rosenbergii de Man)
}

\author{
Ikhsan Khasani, Bambang Gunadi, Lies Emmawati Hadie, Wahyu Pamungkas, dan Sularto
}

\begin{abstract}
ABSTRAK
Penelitian ini bertujuan untuk mengetahui pengaruh lama penyinaran terhadap sintasan dan kecepatan metamorfosis larva udang galah. Penelitian dilakukan di hatcheri udang galah Loka Riset Pemuliaan dan Teknologi Perikanan Budidaya Air Tawar, Sukamandi. Perlakuan lama pencahayaaan yang digunakan adalah: 6 jam terang: 18 jam gelap (6L : 18D), 12 jam terang: 12 jam gelap (12L : 12D); 18 jam terang: 6 jam gelap (18L : 6D); dan 24 jam terang: 0 jam gelap (24L $: 0 D$ ). Masing-masing perlakuan diulang tiga kali. Wadah yang digunakan adalah akuarium persegi panjang volume $20 \mathrm{~L}$ sebanyak 12 buah. Akuarium ditempatkan pada bak kayu $4 \times 1 \times 0,5 \mathrm{~m}^{3}$ berisi air sebagai buffer suhu. Kepadatan awal larva adalah 150 ekor/L. Pakan yang diberikan adalah naupli artemia untuk larva umur 3 hari sedangkan setelah larva berumur 9 hari diberi pakan berupa artemia dan pakan buatan dengan komposisi 55\% protein dan $19,8 \%$ lemak. Rancangan penelitian adalah rancangan acak lengkap. Hasil analisis statistik menunjukkan bahwa lama pencahayaan berpengaruh nyata terhadap kecepatan metamorfosis larva $(P<0,05)$, di mana kecepatan metamorfosis terbaik diperoleh pada periode penyinaran 18 jam terang 6 jam gelap dengan nilai LSI 10,12, dan jumlah pasca-larva pada hari ke-23 sebanyak 633 ekor. Namun demikian periode penyinaran tidak berpengaruh terhadap sintasan $(P>0,05)$, juga terhadap jumlah post-larva pada akhir percobaan $(P>0,05)$.
\end{abstract}

\begin{abstract}
Effect of photoperiod on growth and survival rate of freshwater giant prawn (Macrobrachium rosenbergii de Man). By: Ikhsan Khasani, Bambang Gunadi, Lies Emmawati Hadie, Wahyu Pamungkas, and Sularto

The objective of this experiment is to study the effect of photoperiod on growth and survival rate of giant prawn larvae. The experiment was conducted at Sukamandi Research Institute for Freshwater Fisheries. Photoperiod treatments were: 6 Light (L): 18 Dark (D); $12(L): 12(D) ; 18$ L: 6D; and $24 \mathrm{~L}: O \mathrm{D}$. Each treatment was applied in three replicates and arranged in a complete randomized design. The experiment was conducted in 12 aquaria of 20 liters volume installed in a wooden tank $\left(4 \times 1 \times 0,5 \mathrm{~m}^{3}\right)$ filled with water which used as temperature buffer. Each aquarium was stocked with 3,000 larvae. Artemia nauplii were given to D-3 larvae, while egg custard as artificial food containing $55 \%$ protein and $19,8 \%$ fatty were for D-9. Statistical analysis showed that metamorphosis speed of larvae was significantly affected by photoperiod $(P<0.05)$, but survival rate and post larvae production were not $(P>0.05)$.
\end{abstract}

KEYWORDS: larvae rearing, giant prawn, photoperiod

\section{PENDAHULUAN}

Udang galah (Macrobrachium rosenbergii de Man) merupakan komoditas air tawar yang bernilai ekonomis tinggi serta merupakan komoditas ekspor, sehingga memiliki prospek yang cerah untuk dibudidayakan (Sukadi, 2001). Seiring meningkatnya permintaan pasar baik lokal maupun ekspor terhadap udang galah ukuran konsumsi, permintaan benih (benur) udang galah juga meningkat. Untuk memenuhi kebutuhan tersebut pemerintah telah mengembangkan panti benih udang galah di beberapa daerah seperti
Pelabuhan Ratu, Pangandaran, Adiraja, Sleman, Prigi, dan Bali. Namun demikian sampai saat ini masih dirasakan kesulitan untuk mendapatkan benih yang berkualitas dan berkesinambungan, akibat jumlah produksi yang rendah.

Pertumbuhan larva udang galah sangat dipengaruhi oleh faktor suhu, media tumbuh, kualitas pakan, intensitas cahaya, dan kualitas air (Hadie \& Hadie, 1993). Selama pertumbuhannya, larva udang galah mengalami sebelas kali ganti kulit (moulting) sebelum mencapai stadia benih (PL), dan proses moulting ini

Peneliti pada Loka Riset Pemuliaan dan Teknologi Budidaya Perikanan Air Tawar, Sukamandi 
sangat berpengaruh terhadap tingkat kecepatan pertumbuhan larva (Uno \& Soo, 1969).

Larva udang galah memiliki sifat fototaksis positif (tertarik oleh cahaya), planktonik, serta berkelompok di permukaan (Satyani, 1988). Cahaya sangat mempengaruhi aktivitas larva, khususnya dalam proses mendapatkan energi. Intensitas cahaya yang optimal berpengaruh terhadap tingkat pertumbuhan dan sintasan larva

Intensitas cahaya matahari dipengaruhi oleh musim dan cuaca. Pada dini hari dan menjelang matahari terbenam intensitas cahaya matahari sangat lemah, sehingga untuk memperoleh intensitas cahaya yang optimal dalam pemeliharaan larva udang galah dibutuhkan cahaya buatan, sebagaimana yang di kembangkan di Pusat Pengembangan Udang Galah Universitas Mississipi (D'Abramo et al., 2002)

Penelitian mengenai pengaruh lama pencahayaan telah dilakukan pada beberapa spesies ikan, di antaranya adalah larva kerapu tikus (Cromileptes altivelis), larva teripang pasir (Holothuria scabra), dan ikan lele (Clarias gariepenus). Pada larva kerapu tikus, lama pencahayaan 18 jam terang: 6 jam gelap memberikan pertumbuhan yang lebih baik dibandingkan dengan 24 jam terang: 0 jam gelap dan 12 jam terang: 12 jam gelap. Sedangkan lama penyinaran yang terbaik terhadap sintasan larva diperoleh pada 12 jam terang; 12 jam gelap (Hutapea et al., 1997). Sedangkan Moria et al. (1998), menyatakan bahwa pada larva teripang pasir lama pencahayaan 12 jam terang: 12 jam gelap memberikan derajat sintasan tertinggi dibandingkan lama pencahayaan 24 jam terang: 0 jam gelap dan 18 jam terang: 6 jam gelap. Penelitian pengaruh lama pencahayaan juga telah dilakukan pada yuwana udang galah, dengan hasil lama pencahayaan 24 jam terang: 0 jam gelap memberikan derajat sintasan yang lebih tinggi dibandingkan perlakuan pencahayaan 0 jam terang: 24 jam gelap dan 12 jam terang: 12 jam gelap. Sedangkan pertumbuhan yuwana tidak dipengaruhi oleh lama pencahayaan (Tidwell et al., 2001).

Penerapan lama pencahayaan yang sesuai diharapkan dapat mempercepat proses metamorfosis larva udang galah dan akhirnya dapat meningkatkan efisiensi dan kuantitas produksi panti benih udang galah.

\section{BAHAN DAN METODE}

Penelitian ini dilaksanakan di hatcheri udang galah Loka Riset Pemuliaan dan Teknologi Budidaya Perikanan Air Tawar, Sukamandi-Jawa Barat. Sebagai hewan uji adalah larva udang galah ( $M$. rosenbergii de Man) umur tiga hari ( $\mathrm{H}-3$ setelah menetas) dengan padat tebar 150 ekor/L.
Stok induk udang galah yang digunakan adalah varietas GIMacro. Induk udang galah diberi pakan berupa pelet udang galah komersial dan kerang rucah. Pematangan induk udang dilakukan secara terkontrol dalam bak beton $2 \times 3 \mathrm{~m}^{2}$. Induk betina yang mengandung telur siap menetas disterilisasi dengan merendamnya pada larutan malachite green $1,5 \mathrm{mg} /$ L selama 20 menit, selanjutnya dipindahkan ke bak penetasan berkapasitas $350 \mathrm{~L}$.

Larva udang galah GIMacro dipelihara dengan metode air jernih tanpa plankton bersalinitas 12 permil dalam akuarium ukuran $50 \times 25 \times 30 \mathrm{~cm}$ yang ditempatkan pada bak $4 \times 1 \mathrm{~m}^{2}$ berisi air sebagai penyangga suhu. Air media pemeliharaan larva sebelum digunakan disterilkan dengan sistem klorinasi. Suhu media diusahakan stabil pada kisaran $30^{\circ} \mathrm{C}-31^{\circ} \mathrm{C}$ dengan menggunakan heater. Media pemeliharaan disipon dan diganti sebanyak $50 \%--60 \%$ volume dua hari sekali saat larva berumur tiga sampai 12 hari, dan selanjutnya pergantian air dilakukan setiap hari. Pakan yang digunakan adalah naupli artemia dan pakan buatan (egg custard) dengan bahan baku sesuai dengan rekomendasi Aquacop (1983). Berdasarkan hasil analisis proksimat, pakan buatan yang diberikan mengandung komposisi sebagai berikut: protein $55 \%$; lemak $19,8 \%$; dan abu $7,7 \%$. Pemberian pakan dilakukan sebanyak 7 kali per hari dengan interval 2 jam, dan jumlah pakan sesuai New (1995).

Perlakuan lama pencahayaan yang berbeda diterapkan pada fase pemeliharaan larva yakni mulai dari umur 3 hari $(\mathrm{H} 3)$ sampai dengan umur 30 hari $(\mathrm{H} 30)$. Adapun perlakuannya dirancang sebagai berikut

1.6L : 18D = $\begin{aligned} & \text { pencahayaan } 6 \text { jam terang, } 18 \text { jam } \\ & \text { gelap } \\ 2.12 \mathrm{~L}: 12 \mathrm{D}= & \text { pencahayaan } 12 \text { jam terang, } 12 \text { jam } \\ & \text { gelap } \\ 3.18 \mathrm{~L}: 6 \mathrm{D}= & \text { pencahayaan } 18 \text { jam terang, } 6 \text { jam } \\ & \text { gelap } \\ 4.24 \mathrm{~L}:: 0 \mathrm{D}= & \text { pencahayaan } 24 \text { jam terang, } 0 \text { jam } \\ & \text { gelap }\end{aligned}$

Sumber cahaya yang digunakan adalah lampu 200 watt yang diatur jaraknya dari permukaaan air media pemeliharaan dengan light-meter. Intensitas cahaya yang digunakan adalah 3.000 lux sesuai dengan penelitian pendahuluan. Pengaturan lama pencahayaan menggunakan timer. Masing-masing perlakuan diulang tiga kali dengan rancangan percobaan menggunakan rancangan acak lengkap.

Peubah yang diamati adalah kecepatan metamorfosis yang ditunjukkan dengan nilai LSI (larval stage index), jumlah pasca larva (PL), dan sintasan 
larva. Untuk mendapatkan nilai LSI dilakukan pengambilan larva secara acak sebanyak 30 ekor/ akuarium dan dilakukan pengamatan di bawah mikroskop setiap 3 hari sampai $\mathrm{H}-20$ (saat didapatkan $P L$ 1). Setelah $H-20$ penentuan nilai LSI dirasa tidak memungkinkan karena sudah diperoleh banyak $\mathrm{PL}$. Penghitungan nilai LSI berdasarkan rumus yang dikembangkan oleh Muddox \& Manzi (1976) dalam Aquacop (1983):

$$
\operatorname{LS} 1=\frac{\left(n_{1} \times 1\right)+\left(n_{2} \times 2\right)+\left(n_{3} \times 3\right) s \cdot d\left(n_{k} \times k\right)}{N}
$$

$\begin{array}{lll}1,2,3, \mathrm{k} & = & \text { tingkat stadia larva, } 1 \mathrm{~s} / \mathrm{d} \mathrm{k} \\ \mathrm{n}_{1} & = & \text { jumlah larva pada stadia ke-1 } \\ \mathrm{N} & = & \text { jumlah larva yang diamati (ekor) }\end{array}$

Pola sintasan larva dihitung dengan menggunakan rumus (Effendi, 1979) sebagai berikut:

$$
\mathrm{SR}=\frac{\mathrm{Nt}}{\mathrm{No}} \times 100 \%
$$

$\mathrm{SR}=$ Persentase sintasan

No = Jumlah individu pada awal penelitian (ekor)

$\mathrm{Nt}=$ Jumlah individu pada pengamatan ke-t (ekor)

Data jumlah pasca-larva, derajat sintasan, dan nilai LSI yang diperoleh dianalisis dengan menggunakan analisis sidik ragam (Anova) pada tingkat kepercayaan 95\% dan dilanjutkan dengan uji Duncan (Gomez \& Gomez, 1995).

Pengamatan kualitas air yang meliputi $\mathrm{pH}$ media, salinitas, oksigen terlarut, alkalinitas, amonia, dan nitrit dilakukan setiap minggu, sedangkan suhu media dan ruangan diukur tiga kali sehari (pagi, siang, dan sore).

\section{HASIL DAN BAHASAN}

Hasil pengamatan jumlah rata-rata pasca-larva pada hari ke-23 $(\mathrm{H}-23)$ dan hari ke-30 $(\mathrm{H}-30)$ pada masing-masing perlakuan periode penyinaran disajikan pada Tabel 1

Jumlah pasca-larva pada hari ke-23 untuk perlakuan $18 \mathrm{~L}$ : 6 D yakni 633 ekor berbeda nyata $(P<0,05)$ dibandingkan dengan perlakuan 6 L: $18 \mathrm{D}$ (67 ekor) dan 12 L: 12 D (187 ekor). Demikian juga perlakuan $24 \mathrm{~L}: 0 \mathrm{D}$ (411 ekor) dengan perlakuan 6 L: 18 D (67 ekor). Namun demikian pada akhir pengamatan ( $\mathrm{H}-$ 30) jumlah pasca-larva pada semua perlakuan tidak saling berbeda nyata $(P>0,05)$. Jumlah pasca-larva pada hari ke-30 yang tidak berbeda nyata diduga karena adanya kebiasaan larva (stadia 10 dan 11) yang melompat dari media pemeliharaan dan didapatkan mati pada dinding sekat antar perlakuan. Dari hasil pengamatan harian diperoleh informasi bahwa jumlah rata-rata larva yang kering (mati) di luar media lebih banyak pada perlakuan pencahayaan yang lebih lama, sehingga tingkat kegagalan proses metamorfose larva yang sudah mencapai stadia 10 dan 11 menjadi $\mathrm{PL}$ juga lebih banyak pada perlakuan pencahayaan yang lebih lama. Namun demikian pada akhir penelitian $(\mathrm{H}-$ 30) diperoleh sisa larva dalam jumlah yang berbeda. Jumlah larva yang belum mencapai PL pada perlakuan pencahayaan yang lebih lama ternyata lebih sedikit dibandingkan pada pencahayaan pendek. Jumlah rata-rata sisa larva pada akhir penelitian sebagai berikut : perlakuan 6 L: 18 D (257 ekor); 12 L: 12 D (195 ekor); $18 \mathrm{~L}: 6 \mathrm{D}$ (45 ekor); dan perlakuan $24 \mathrm{~L}: 0$ D (17 ekor). Hal ini menunjukkan bahwa larva yang mengalami pertumbuhan lebih lambat banyak terjadi pada perlakuan pencahayaan yang lebih pendek.

Nilai LSI yang merupakan gambaran tingkat perkembangan larva disajikan pada Tabel 2

Tabel 1. Jumlah pasca larva ( $\mathrm{PL}$ ) udang galah (M. rosenbergii de Man) pada hari ke-23 (H-23) dan hari ke-30 $(\mathrm{H}-30)$ dengan lama penyinaran berbeda

Table1. Number of giant prawn post larvae (M. rosenbergii de Man) at day of $23(\mathrm{H}-23)$ and day of $30(\mathrm{H}-$

\begin{tabular}{|c|c|c|}
\hline \multirow{2}{*}{$\begin{array}{l}\text { Perlakuan } \\
\text { Treatment }\end{array}$} & \multicolumn{2}{|c|}{$\begin{array}{l}\text { Jumlah pasca larva (ind.) } \\
\text { Number of post larvae (ind.) }\end{array}$} \\
\hline & $\mathrm{H}-23$ & $\mathrm{H}-30$ \\
\hline $6 \mathrm{~L}: 18 \mathrm{D}$ & $67^{c}$ & $1,411^{a}$ \\
\hline $12 \mathrm{~L}: 12 \mathrm{D}$ & $187^{b c}$ & $1,185^{\mathrm{a}}$ \\
\hline $18 \mathrm{~L}: 6 \mathrm{D}$ & $633^{a}$ & $1,483^{a}$ \\
\hline $24 \mathrm{~L}: 0 \mathrm{D}$ & $411^{\mathrm{ab}}$ & $1,209^{a}$ \\
\hline
\end{tabular}
30) with different lengths of photoperiod

Keterangan $($ Note $): L($ light = terang $) D($ dark = gelap $)$ 
Tabel 2. Nilai LSI larva udang galah (M. rosenbergii de Man) pada H-20 dengan lama penyinaran berbeda Table 2. Larvae stage index (LSI) of giant prawn larvae (M. rosenbergii de Man) at $\mathrm{H}-20$ with different lengths of photoperiod

\begin{tabular}{cc}
\hline $\begin{array}{c}\text { Perlakuan } \\
\text { Treatment }\end{array}$ & $\begin{array}{c}\text { Nilai LSI } \\
\text { LSI value }\end{array}$ \\
\hline $6 \mathrm{~L}: 18 \mathrm{D}$ & $9.52^{\mathrm{bc}}$ \\
$12 \mathrm{~L}: 12 \mathrm{D}$ & $9.08^{\mathrm{c}}$ \\
$18 \mathrm{~L}: 6 \mathrm{D}$ & $10.12^{\mathrm{a}}$ \\
$24 \mathrm{~L}:$ O D & $10.04^{\mathrm{ab}}$ \\
\hline
\end{tabular}

Hasil analisis sidik ragam nilai LSI juga memperlihatkan adanya perbedaan yang nyata $(P<0,05)$ antara perlakuan pencahayaan $18 \mathrm{~L}: 6 \mathrm{D}$ dengan $6 \mathrm{~L}: 18 \mathrm{D}$ dan $12 \mathrm{~L}: 12 \mathrm{D}$ serta perlakuan 24 L: $O D$ dengan $12 \mathrm{~L}: 12$

Hasil uji lanjutan (Duncan) memperlihatkan bahwa kecepatan pertumbuhan larva pada periode penyinaran $18 \mathrm{~L}: 6 \mathrm{D}$ dan $24 \mathrm{~L}: 0 \mathrm{D}$ lebih baik (nilai LSI pada $\mathrm{H}-20$ dan jumlah pasca-larva pada $\mathrm{H}-23$ ) dibandingkan perlakuan $6 \mathrm{~L}: 18 \mathrm{D}$ dan $12 \mathrm{~L}: 12 \mathrm{D}$. Dari hasil ini terlihat bahwa lama pencahayaan antara 18--24 jam diperlukan dalam pemeliharaan larva udang galah. Menurut Brown et al. (1980), cahaya dan suhu berpengaruh terhadap kehidupan ikan melalui kerja sistem syaraf dan proses metabolisme. Selanjutnya dinyatakan pula bahwa perubahan periode penyinaran juga berpengaruh terhadap kerja kelenjar pituitari yang merupakan organ kecil pada otak ikan. Spotte (1970) juga menyatakan bahwa pengaruh cahaya terhadap larva ikan sebagaimana pengaruh suhu yaitu pada proses metabolisme. Tandler \& Help dalam Duray \& Kohno (1988) menyatakan bahwa pencahayaan secara terus-menerus dapat memacu pertumbuhan larva ikan melalui peningkatan kemampuan larva dalam mendapatkan makanannya.

Nilai L.SI yang diperoleh menunjukkan bahwa cahaya berpengaruh terhadap kecepatan metamorfosis larva udang galah. Hal ini terlihat dari semakin tingginya nilai LSI yang diperoleh pada perlakuan pencahayaan yang lebih lama 18 jam terang: 6 jam gelap dan 24 jam terang: 0 jam gelap Angka jumlah pasca-larva pada $\mathrm{H}-23$ juga menunjukkan adanya pengaruh lama pencahayaan terhadap kecepatan metamorfosis larva udang galah.

Hasil pengamatan derajat sintasan pada akhir penelitian disajikan pada Tabel 3. Hasil analisis sidik ragam menunjukkan bahwa sintasan larva udang galah pada semua perlakuan pencahayaan tidak berbeda nyata $(P>0,05)$.

Derajat sintasan larva pada akhir penelitian $(\mathrm{H}-30)$ yang tidak beda nyata diduga karena semua perlakuan pencahayaan yang diberikan masih memungkinkan bagi larva untuk memenuhi kebutuhan energi minimum untuk sintasannya, sementara faktor-faktor pembatas seperti suhu, $\mathrm{pH}$, salinitas, amonia, dan nitrit dalam kondisi yang relatif sama.

Larva udang galah bersifat fototaksis positif, yakni aktif mencari makan dengan adanya rangsangan cahaya (Satyani, 1988). Berdasarkan hasil pengamatan, larva yang telah mencapai stadia 10 banyak yang meloncat menuju sumber sinar. Sifat ini mengakibatkan banyaknya larva mati karena keluar dari media pemeliharaan dan menempel pada dinding sekat antar perlakuan.

Pada perlakuan 24 jam terang: 0 jam gelap diperoleh jumlah rata-rata pasca larva pada hari ke23 yang lebih sedikit (633 ekor) dari perlakuan 18 jam terang: 6 jam gelap (411 ekor). Kondisi ini diduga karena jumlah larva yang loncat dan mati pada

Tabel 3. Sintasan larva udang galah (M. rosenbergii de Man) dengan lama penyinaran berbeda selama 30 hari pemeliharaan

Table 3. Survival rates of giant prawn larvae (M. rosenbergii de Man) at different length of photoperiod during 30-day rearing

\begin{tabular}{|c|c|c|c|}
\hline $\begin{array}{l}\text { Perlakuan } \\
\text { Treatment }\end{array}$ & $\begin{array}{l}\text { Jumlah awal (ind.) } \\
\text { Initial number (ind.) }\end{array}$ & $\begin{array}{l}\text { Jumlah akhir (ind.) } \\
\text { Final number (ind.) }\end{array}$ & $\begin{array}{c}\text { Sintasan }(\%) \\
\text { Survival rate (\%) }\end{array}$ \\
\hline $6 \mathrm{~L}: 18 \mathrm{D}$ & 3,000 & 1,669 & $56^{a}$ \\
\hline $12 \mathrm{~L}: 12 \mathrm{D}$ & 3,000 & 1,380 & $46^{a}$ \\
\hline $18 \mathrm{~L}: \quad 6 \mathrm{D}$ & 3,000 & 1,528 & $51^{a}$ \\
\hline $24 \mathrm{~L}: \quad 0 D$ & 3,000 & 1,226 & $41^{\mathrm{a}}$ \\
\hline
\end{tabular}


Tabel 4. Nila rata-rata kualitas air selama pemeliharaan larva udang galah

Table 4. Average values of water quality during larvae rearing of giant prawn

\begin{tabular}{|c|c|c|c|c|c|c|c|c|}
\hline $\begin{array}{l}\text { Perlakuan } \\
\text { Treatment }\end{array}$ & $\mathrm{pH}$ & $\begin{array}{c}\text { Salinitas } \\
\text { Salinity } \\
\text { (ppt) }\end{array}$ & $\begin{array}{c}\text { Amonia } \\
\text { Ammonia } \\
(\mathrm{mg} / \mathrm{L})\end{array}$ & $\begin{array}{l}\text { Nitrit } \\
\text { Nitrite } \\
\text { (mg/L) }\end{array}$ & $\begin{array}{c}\text { Suhu udara } \\
\text { Air } \\
\text { temperature } \\
\left({ }^{\circ} \mathrm{C}\right)\end{array}$ & $\begin{array}{c}\text { Suhu air } \\
\text { Water } \\
\text { temperature } \\
\left({ }^{\circ} \mathrm{C}\right)\end{array}$ & $\begin{array}{c}\text { Alkalinitas } \\
\text { Alkalinity } \\
\text { (mg/L) }\end{array}$ & $\begin{array}{c}\text { Oksigen } \\
\text { terlarut } \\
D O \\
(\mathrm{mg} / \mathrm{L})\end{array}$ \\
\hline $6 \mathrm{~L}: 18 \mathrm{D}$ & 8.5 & 12 & 0.5 & $0--0.8$ & & & & \\
\hline $12 \mathrm{~L}: 12 \mathrm{D}$ & $8.2--8.5$ & 12 & $0.1--0.8$ & $0--1.0$ & 36--37 & 30--33 & $160--230$ & 4.6--6.5 \\
\hline $18 \mathrm{~L}: 18 \mathrm{D}$ & $8.2--8.5$ & 12 & $0.1--0.8$ & $0--0.6$ & $36--37$ & $31--33$ & $160--250$ & 4.3--7.5 \\
\hline 24L : O D & $8.2--8.5$ & 12 & $0.1--0.6$ & $0--0.6$ & $36--37$ & $32--33$ & $160--250$ & 4.1--7.0 \\
\hline
\end{tabular}

perlakuan 24 jam terang 0 jam gelap lebih banyak dibandingkan pada perlakuan 18 jam terang 6 jam gelap. Fenomena ini juga bisa disebabkan oleh sifat kanibalisme yang dimiliki larva udang galah. Pemberian pakan terakhir dilakukan pada pukul 18.30 WIB, sehingga kemungkinan besar setelah enam jam jumlah artemia yang diberikan sudah tidak memadai, sementara dengan masih adanya rangsangan pencahayaan, larva tetap aktif mencari makan dan memangsa larva lain yang sedang moulting (lemah). Pengamatan terhadap artemia yang tersisa di media pemeliharaan pada pagi hari (pukul 06.00 WIB) didapatkan informasi bahwa pada perlakuan pencahayaan $18 \mathrm{~L}: 6 \mathrm{D}$ dan $24 \mathrm{~L}: 0 \mathrm{D}$ artemia sudah habis, sementara pada perlakuan $6 \mathrm{~L}: 18 \mathrm{D}$ dan $12 \mathrm{~L}$ : $12 \mathrm{D}$ masih ditemukan artemia dalam jumlah cukup banyak.

Hasil pengamatan kualitas air menunjukkan bahwa setelah larva berumur 9 hari dan diberi makanan buatan (egg custard), kualitas air mengalami penurunan drastis, yang ditunjukkan dengan cukup tingginya kandungan amonia dan nitrit. Namun demikian dengan metode pergantian air secara teratur sebanyak $50 \%$ $-60 \%$ volume sesuai dengan prosedur Aquacop (1983) dapat diperoleh kembali kualitas media pemeliharaan yang lebih baik. Kualitas air antar perlakuan relatif sama. Hal ini dikarenakan pemeliharaan dilaksanakan pada kondisi yang relatif sama dengan ditunjang oleh sarana sirkulasi air dengan suhu terkontrol (heater otomatis), dan pergantian air payau dengan salinitas dan $\mathrm{pH}$ yang sama secara teratur. Kadar oksigen terlarut antar perlakuan juga relatif sama karena sarana penelitian dilengkapi dengan sarana aerasi yang memadai. Secara umum kualitas air media pemeliharaan masih layak untuk kehidupan larva udang galah.

\section{KESIMPULAN}

Lama periode terang (antara 18--24 jam) mampu meningkatkan kecepatan pertumbuhan larva udang galah ( $M$. rosenbergii de Man). Namun demikian lama periode pencahayaan tidak memberikan pengaruh yang nyata terhadap derajat sintasan dan jumlah post larva yang dihasilkan pada akhir penelitian.

\section{DAFTAR PUSTAKA}

Aquacop. 1983. Intensive larval rearing in clear water of Macrobrachium rosenbergii at Center Oceanologique Tahiti. Handbook of mariculture biology 1. Crustacean Aquacult. p. 179--187.

Brown, E.E. and J.B. Gratzek. 1980. Fish Farming Hand Book. The AVI Publishing Company Inc. West Pott. Connecticum. $390 \mathrm{pp}$.

D'Abramo, L.R., M.W. Brunson, and M.E. Fondren. 2002. Freshwater Prawns Hatchery and Nursery Management. Mississippi State University Press. Mississippi. $10 \mathrm{pp}$

Duray, M. and H. Kohno. 1988. Effects of Continuous Lighting on Growth and Survival of First Feeding Larval Rabbitfish (Siganus guttatus). Aquaculture 72: 73-79 .

Effendi, M.I. 1979. Metoda Biologi Perikanan. Yayasan Dewi Sri. Bogor. 112 pp.

Gomez, A.K. and A.A. Gomez. 1995. Prosedur Statistik untuk Penelitian Pertanian. Edisi kedua. Universitas Indonesia Press. 689 pp.

Hadie, W. dan L.E. Hadie. 1993. Pembenihan Udang Galah Usaha Industri Rumah Tangga. PT Kanisius. Yogyakarta. $110 \mathrm{pp}$.

Hutapea, J.H., Wardoyo, dan K.M. Setiawati. 1997. Pembesaran larva kerapu tikus (Cromileptes altivelis) dengan tingkat fotoperiod yang berbeda. J. Pen. Per. Indonesia, III(4): 24--29.

Moria, S.B., K. Sugama, dan S. Made. 1998. Pengaruh periode penyinaran (fotoperiod) terhadap pertumbuhan dan sintasan larva teripang pasir (Holothuria scabra). Prosiding Seminar Teknologi Perikanan Pantai. Pusat Penelitian dan Pengembangan Perikanan dan Loka Penelitian Perikanan Pantai Gondol, Bali. p. 133--136.

New, M.B. 1995. Status of Freshwater Prawn Farming: A Review. Asean EEC Aquaculture Development and Coordination Programme, Bangkok, Thailand. 26: 1-54 . 
Satyani, D. 1988. Biologi dalam Haniah, H.S, F. Cholik, D. Satyani, R. Arifudin, W. Ismail. Petunjuk Teknis Pengoperasian Pembenihan Udang Galah. Badan Penelitian dan Pengembangan Pertanian. Pusat Penelitian dan Pengembangan Perikanan. 123 pp.

Spotte, S.H. 1970. Fish and Invertebrate Culture, Wiley Interscience. New York. 145 pp.

Sukadi, F. 2001. Kebijakan pengembangan budidaya udang galah (Macrobrachium rosenbergii). Prosiding
Workshop Hasil Penelitian Budi Daya Udang Galah. Pusat Riset Perikanan Budidaya, p. 11--14.

Tidwell, J.H., S. Coyle, and A.V. Arnum. 2001. The effect of photoperiod on growth and survival of juvenile freshwater prawn (Macrobrachium rosenbergii) in tank nursery. J. of Applied Aquaculture. (55), 4: 41--48

Uno, Y. and K.C. Soo. 1969. Larval development of Macrobrachium rosenbergii (de Man) in the laboratory. J. of Tokyo University of Fisheries. 55(2): 175. 